\title{
KHAIRU UMMAH DALAM PANDANGAN K.H. IRFAN HIELMY (1955- 2010)
}

\author{
Ahmad Labib Majdi \\ UIN Sunan Kalijaga Yogyakarta (alabibm9@gmail.com)
}

\begin{abstract}
This paper discusses about K.H. Irfan Hielmy and his ideas about khairu ummah. Khairu ummah is a phrase in the Qur'an that shows an ideal society that has three dimensions of amalgam, amr bi al-ma`ruf, nahy 'an al-munkar and tu'minuna billah. Moving on from these descriptions, K.H. Irfan Hielmy seeks to provide a step for the people and nation of Indonesia to bring civilization khairu ummah, so as to erode the nature and bigotry, exclusive and intolerant. With the beginning of Muslims themselves, according to K.H. Irfan Hielmy, the mutual respect between religious people is not just mere wishful thinking. Coupled with the socio-political conditions of the people who were warm discuss the concept of State, decent proposed and put forward ideas that are expected to be moderate concrete and tangible solutions to the sustainability of the Unitary Republic of Indonesia. The realization of khairu ummah is the situation and condition of all people can live together and side by side without any mutual accusations that are now becoming more frequent.
\end{abstract}

Keywords: biography, k.h. irfan hielmy, khairu ummah thought

\begin{abstract}
Abstrak
Tulisan ini membicarakan tentang K.H. Irfan Hielmy dan pemikirannya tentang khairu ummah. Khairu ummah adalah sebuah frasa dalam al-Quran yang menunjukkan sebuah tatanan masyarakat ideal yang memiliki tiga dimensi amaliah, yaitu amr bi al-ma`ruf, nahy `an al-munkar dan tu`minuna billah. Beranjak dari keterangan tersebut, K.H. Irfan Hielmy berusaha memberikan langkah bagi umat dan bangsa di Indonesia untuk mewujudkan peradaban khairu ummah, sehingga mampu mengikis sifat dan sikap fanatik, ekslusif dan intoleran. Dengan berawal dari umat Islam sendiri, menurut K.H. Irfan Hielmy, maka saling menghormati dan menghargai antar dan intra umat beragama bukan sekedar angan-angan belaka. Ditambah dengan kondisi sosial-politik masyarakat yang tengah hangat membicarakan konsep Negara, layak dikemukakan dan diketengahkan pemikiran-pemikiran moderat yang diharapkan mampu menjadi solusi konkret dan nyata terhadap keberlangsungan Negara Kesatuan Republik Indonesia. Realisasi khairu ummah adalah situasi dan kondisi seluruh masyarakat dapat hidup bersama-sama dan saling berdampingan tanpa ada saling tuding-menuding dan tuduh-menuduh yang kini justru semakin sering dilakukan.
\end{abstract}

Kata Kunci: biografi, k.h. irfan hielmy, pemikiran khairu ummah

\section{A. Pendahuluan}

Hubungan agama dan negara, selalu menjadi topik yang menarik bagi para cendekiawan dan intelektual, baik muslim maupun non-muslim. Hampir selama berabad-abad, diskursus ini selalu menjadi subyek menarik untuk diperbincangkan. Topik ini terus berlangsung dari masa ke masa, generasi ke generasi dan tidak pernah terselesaikan secara tuntas. 
Bahkan, melalui perkembangan ilmu pengetahuan muncul teori-teori baru dalam usahanya menjembatani hubungan agama dan negara. ${ }^{1}$ Bagi kalangan umat Islam sendiri, topik tersebut barangkali dapat ditelusuri berasal dari dua persoalan. Pertama, apakah kerasulan Muhammad SAW. mempunyai kaitan dengan masalah politik, atau apakah Islam merupakan agama yang terkait erat dengan urusan politik kenegaraan dan pemerintahan. Kedua, apakah sistem dan bentuk pemerintahan, sekaligus prinsip-prinsipnya terdapat pula dalam Islam. ${ }^{2}$

Kemunculan kedua persoalan tersebut merupakan konsekuensi logis dari komprehensifnya ajaran Islam. Ajaran Islam yang bersumber dari Quran dan Hadis merupakan ajaran yang hak lagi sempurna. Allah SWT. melalui firman dan utusan-

\footnotetext{
1 Perdebatan mengenai hubungan Islam dan politik memang telah mengakar, khususnya bagi para pemikir muslim. Akan tetapi, masyarakat muslim yang awam justru kurang melihat adanya hubungan Islam dan politik. Muslim awam cenderung menganggap Islam adalah agama individual dan lupa akan realita kolektivitas Islam. Hal ini disebabkan karena pemahaman yang kurang utuh terhadap cakupan ajaran Islam. Dengan demikian, wajar jika upaya integrasi umat selalu mengalami kebuntuan, karena memang tidak adanya kesadaran bahwa Islam adalah sebuah komunitas. Kuntowijoyo, Identitas Politik Umat Islam (Bandung: Mizan, 1997), Cet. I, hlm. 27.

${ }^{2}$ Munawir Sjadzali, Islam dan Tata Negara: Ajaran, Sejarah dan Pemikiran (Jakarta: UI Press, 1993), hlm. 2.
}

Nya telah memberikan pedomanpedoman bagi manusia untuk hidup sesuai fitrahnya, yaitu kecenderungan kepada kebaikan (hanîf). ${ }^{3}$ Dalam kedua pedoman hidup tersebut, telah diatur mengenai tata cara hidup manusia meliputi segala aspek kehidupan bukan saja mengenai akidah, syariat dan akhlak, tetapi juga seperti berkenaan dengan persoalan sosial, politik, budaya, dan pendidikan, sehingga wajar apabila beberapa pemikir yang memiliki pemahaman yang komprehensif menyebut Islam sebagai agama universal. $^{4}$

3 Perihal "cenderung kepada kebaikan" atau "hanîf", Nurcholish Madjid telah menjelaskan bahwa berislam dengan hanîf adalah selaras dengan fitrah manusia. Keislaman yang hanîf dalam pandangan Nurcholish adalah fondasi teologis untuk masyarakat muslim agar bisa menerima sepenuhnya ide-ide kemajuan yang telah direnungkan dalam sejarah pergulatan pemikiran modern. Oleh sebab itu, jika keislaman hanâfiyat al-samhah mampu diinternalisasikan kepada individu-individu muslim, tentu mereka akan menjadi sosok yang lebih terbuka pada kebenaran, yang membawa pada kelapangan hidup, sehingga tidak ada lagi sikap-sikap eksklusif, fanatik dan intoleran. Buddhy Munawwar-Rachman dan Elza Peldi Taher, Keislaman Yang Hanif (Depok: Imania, 2013), hlm. vi.

${ }^{4}$ Salah satu pemikir yang menjelasan mengenai universalisme Islam adalah Nurcholish Madjid. Dalam pandangannya, universalisme Islam memiliki tiga item penting, yaitu universalisme manusia, universalisme konsep manusia dan universalisme konsep kenabian. Nurcholish Madjid, Islam Doktrin dan Peradaban: Sebuah Telaah Kritis tentang Masalah Keimanan, Kemanusiaan dan Kemodernan (Jakarta: 
Menurut Harun Nasution, keterkaitan antara Islam dan Negara adalah hal pertama yang timbul dalam sejarah Islam. Hal ini terlihat dari sosok Nabi Muhammad SAW. ketika berada di Madinah. Nabi SAW. tidak hanya mempunyai sifat utusan Allah SWT., tetapi juga sifat kepala Negara. Dan sebagai kepala Negara, setelah wafat harus diganti oleh orang lain untuk memimpin negara yang ditinggalkan. ${ }^{5}$ Sementara itu, Munawir Sjadzali menginformasikan bahwa di kalangan umat Islam sampai saat ini, setidaknya dapat dibagi tiga aliran dalam memandang hubungan Islam dan Negara. (1) mereka yang berpendirian bahwa Islam bukan semata-mata yang hanya menyangkut hubungan manusia dengan Tuhan, melainkan mencakup segala aspek kehidupan termasuk politik. Oleh sebab itu sistem politk yang harus diteladani adalah sistem politik yang telah dilaksanakan Nabi Muhammad dan Khilafah Rasyidah. (2) mereka yang berpandangan bahwa Islam adalah agama yang tidak berhubungan dengan urusan politik. Menurut mereka, Nabi Muhammad hanya seorang utusan dengan tugas tunggal mengajak

Yayasan Wakaf Paramadina, 1992), hlm. 427433.

${ }^{5}$ Harun Nasution, Islam Ditinjau dari Berbagai Aspeknya, Jilid I (Jakarta: UI Press, 2013), hlm. 92. manusia kepada kehidupan yang mulia dan Nabi Muhamamd tidak pernah dimaksudkan untuk mengurusi persoalan politik. (3) mereka yang berpendirian bahwa Islam memang tidak memiliki pedoman khusus yang rinci dan utuh mengenai persoalan politik, tetapi terdapat seperangkat tata nilai etika bagi kehidupan perpolitikan. ${ }^{6}$ Aliran pertama disebut dengan aliran paradigma integratif, aliran kedua disebut dengan aliran paradigma sekuler dan aliran ketiga disebut dengan aliran paradigma simbiotik. ${ }^{7}$

Dalam konteks Indonesia, dapat dimunculkan beberapa alasan mengenai hangatnya perdebatan diskursus Islam dan Negara di Indonesia. Pertama, perbincangan hubungan Islam dan Negara di Indonesia kurang lebih memperlihatkan tingkat otonomi dan pengakuan agama sebagai hak asasi individual yang seharusnya diserahkan pada lembaga-lembaga agama yang bebas dan otonom. Hubungan ini memperlihatkan tingkat otoritas individu dan

6 Secara umum dan agar mudah dikategorisasikan, maka kebanyakan para peneliti menyebut aliran pertama sebagai aliran pemikir tradisionalis, aliran kedua sebagai aliran pemikir sekularis dan ketiga aliran pemikir moderat. Sjadzali, Islam dan Tata Negara, hlm. 1-2.

7 Abdul Hamid Yahya dan Yaya, Pemikiran Modern Dalam Islam (Bandung: Pustaka Setia, 2010), hlm. 377-379. 
kelompok-kelompok keagamaan dalam masyarakat untuk mengatur sendiri peribadatan sesuai keyakinan masing-masing. Kedua, perbincangan hubungan Islam dan Negara di Indonesia menjadi suatu hal penting karena persoalan ini merupakan gejala masyarakat yang berakar dari munculnya sekularisasi. Ketiga, persoalan kontekstualisasi bentuk negara merupakan hal yang penting dalam hubungan Islam dan Negara di Indonesia, dikarenakan Indonesia adalah negara yang memiliki tingkat pluralitas yang tinggi, sehingga tingkat sentimen primordial dalam masyarakat Indonesia pun sangat tinggi. ${ }^{8}$

Dewasa ini, hubungan Islam dan Negara di Indonesia semakin hangat dan marak diperbincangkan bersamaan dengan kebangkitan anarkisme, radikalisme dan intoleransi antar-umat beragama. Wacana kekinian bukan lagi terfokus pada perdebatan akademik tentang Islam dan Negara di Indonesia, tetapi justru menjurus pada membenturkan Islam dengan praktik politik di Indonesia yang dianggap tidak sesuai ajaran Islam. Padahal, bagi Indonesia sebagai sebuah bangsa majemuk, unsur-unsur anarkisme, radikalisme

${ }^{8}$ M. Tahir, "Hubungan Agama dan Negara di Indonesia dalam Pandangan Nurcholish Madjid", Jurnal Komunikasi dan Sosial Keagamaan, Vol. XV No. 1, Juni 2012, hlm. 37-38. dan intoleransi harus dikubur dalamdalam, karena jika tidak akan menimbulkan kekacauan dan perpecahan. Menurut Din Syamsudin, Indonesia saat ini dengan dasar negara Pancasila dan bentuk pemerintahan republik demokrasi adalah bentuk final dan ideal. Ia memandang bahwa Pancasila adalah sebuah common platform dan common denominator atau dalam bahasa al-Quran disebut kalimatun sawa'. Oleh sebab itu, tidak perlu adanya perubahan dasar dan bentuk negara, apalagi lewat jalan kekerasan.

Perkembangan diskursus hubungan Islam dan politik yang tak kunjung menemukan titik temu, maka layak untuk dikemukakan kembali pandangan dan respon mengenai hubungan Islam dan Negara di Indonesia. Tulisan ini akan berusaha menguraikan pandangan salah seorang ulama terkait hubungan Islam dan Negara di Indonesia yang dianggap penulis masuk pada kategori paradigma

\footnotetext{
${ }^{9}$ Lebih lanjut, menurut Din Syamsuddin dengan penerimaan Pancasila sebagai dasar negara dari Indonesia, maka wilayah Indonesia menjadi wilayah perjanjian dan kesakisan, sehingga negaranya pun disebut dengan Dâr al- 'Ahd dan Dâr al-Syâhadah. Din Syamsuddin, "NKRI: Negara Perjanjian dan Kesaksian", dalam Akhmad Sahal dan Munawir Aziz (ed.), Islam Nusantara: Dari Ushûl Fiqh Hingga Faham Kebangsaan (Bandung: Mizan, 2015), hlm. 280-283.
} 
simbiotik. Ulama tersebut bernama K.H. Irfan Hielmy. Dapat dikatakan bahwa Irfan Hielmy memakai paradigma berpikir moderatsimbiotik, sebab pemikirannya mengenai khairu ummah memiliki kaitan hubungan Islam dan Negara di Indonesia. Menurutnya, Islam dan Negara tidak boleh dipisahkan, karena satu sama lain saling terkait. Meskipun Islam, menurutnya, tidak menyebutkannya secara eksplisit, hanya sekedar prinsip-prinsip dasar saja. Justru hikmah yang didapatkan dari sini adalah bahwa universalitas ajaran Islam akan terus terjaga dan tetap relevan sepanjang zaman, khususnya dalam konteks situasi dan kondisi Indonesia sekarang ini. ${ }^{10}$ Ia menambahkan bahwa tidak ada kontradiksi antara Islam dan Negara, sehingga pengkajian dalam usaha untuk menemukan kesesuain antara keduanya adalah sebuah keniscayaan.

Berdasarkan persoalan yang telah dikemukan di atas, maka pemikiran K.H. Irfan Hielmy tentang khairu ummah menemukan korelasinya dalam penelitian ini. Tulisan ini bukan hanya untuk memberikan alternatif baru dengan menyingkirkan atau mengeliminasi pemikiran-pemikiran terdahulu

${ }^{10}$ Irfan Hielmy, Wacana Islam: Bahan Telaah Anak Bangsa (Ciamis: Pusat Informasi Pondok Pesantren Darussalam, 2000), hlm. 18. mengenai hubungan Islam dan politik di Indonesia, tetapi bisa jadi justru memperkuat pemikiranpemikiran terdahulu sekaligus menambahkan apa yang belum terdapat pada pemikiran yang lalu. Selain itu, tulisan ini merupakan pengantar pemahaman pembaca mengenai pemikiran K.H. Irfan Hielmy yang pada kesempatan lain akan dibahas secara lebih rinci mengenai pemikiran-pemikirannya di berbagai bidang. Penelitian ini adalah penelitian mengenai sejarah pemikiran atau sejarah intelektual. Sejarah intelektual bertugas untuk membicarakan pemikiran yang berpengaruh, melihat konteks sejarah tempat muncul, tumbuh, dan berkembangnya serta pengaruh pemikiran. Pendekatan yang digunakan adalah pendekatan biografik intelektual dan pendekatan sosiologis. Pendekatan biografik intelektual adalah suatu pendekatan yang mengarah pada usaha untuk mengungkapkan kenyataankenyataan hidup dari subyek yang sedang diteliti, pengaruh yang diterima subyek dalam masa formatif hidupnya, sifat dan watak subyek terhadap perkembangan suatu aspek kehidupan. $^{11}$ Pendekatan biografik intelektual digunakan untuk mengungkapkan latar belakang K.H.

11 Sidi Gazalba, Pengantar Sejarah Sebagai Ilmu (Jakarta: Bhatara, 1996), hlm. 177. 
Irfan Hielmy dengan pemikirannya mengenai khairu ummah. Sementara itu, pendekatan sosiologis, sebagaimana dijelaskan oleh Weber, tujuan penggunaannya dalam kajian sejarah adalah untuk memahami arti subyektif dari kelakuan sosial, sehingga yang dicari adalah tujuan dari seorang individu dalam melakukan sebuah tindakan yang berkaitan dengan peristiwa-peristiwa kolektif. $^{12}$ Penelitian dengan menggunakan pendekatan sosiologis berusaha untuk mengungkapkan tujuan pemikiran K.H. Irfan Hielmy yang dianggap sebagai sebuah tindakan responsif atas peristiwaperistiwa yang terjadi saat zamannya. Penulis berharap bahwa penelitian ini akan menjadi suatu inspirasi dalam kehidupan umat dan bangsa.

\section{B. Biografi K.H. Irfan Hielmy}

K.H. Irfan Hielmy dilahirkan pada bulan Ramadhan malam Jumat, bertepatan dengan 25 Desember 1931 M (1933 di Ijazah SR) di Kampung Kandang Gajah, Dusun Cidewa, Desa Dewasari, Kecamatan Cijeungjing, Kabupaten Ciamis. ${ }^{13}$ Ia lahir dari pasangan suami istri Kyai

${ }^{12}$ Dudung Abdurahman, Metodologi Penelitian Sejarah Islam (Yogyakarta: Ombak, 2011) hlm. 12.

${ }^{13}$ Eulis Sri Rosyidatul Badriyyah, K.H. Irfan Hielmy: Pemimpin Moderat Panutan Umat (Bandung: Mega Rancage, 2016), hlm. 21.
Ahmad Fadlil bin H. Abdul Jalal bin Uyut Masitoh dan Siti Maemunah binti Siti Fatimah binti Uyut Eyang Audaya. Jika dilihat dari silsilahnya, ia memiliki garis keturunan ulama $^{14}$ dan bangsawan. Dari garis keturunan ayahnya yang pada waktu itu juga merupakan pimpinan Pondok Pesantren Cidewa ${ }^{15}$ dan masih dari garis keturunan ayahnya yaitu dari neneknya yang bernama Raden Natamirah binti Raden Bratakusumah yang waktu itu menjabat sebagai Wedana Rancah. ${ }^{16}$ Ia dididik oleh ayahandanya untuk melaksanakan salat wajib lima waktu secara berjamaah dan membiasakan untuk melaksanakan salat sunah dhuha serta salat sunah tahajud 11 rakaat di sepertiga malam. ${ }^{17}$ K.H. Irfan Hielmy kecil diberikan pendidikan akhlak atau etika oleh ayahandanya dengan berlandaskan pada Al-Qur'an dan Sunah Rasul yaitu melalui penuturan kisah-kisah

\footnotetext{
${ }^{14}$ Yudi Latif membagi dua kategori dari ulama, yaitu intelek ulama dan ulama intelek (clerical intelligentsia). Menurutnya, yang dimaksud intelek ulama adalah para inteligensia yang melek pengetahuan agama, sedangkan yang dimaksud ulama intelek adalah ulama yang melek pengetahuan modern. Yudi Latif, Inteligensia Muslim dan Kuasa: Genealogi Inteligensia Muslim Indonesia Abad ke-20 (Jakarta: Democracy Project, 2012), hlm. 31-32.

${ }^{15}$ Cikal bakal Pondok Pesantren Darussalam Ciamis Jawa Barat.

${ }^{16}$ Dedi Ahimsa dan Yussi Dewi Hastuti, Ziarah Menapaki 80 Tahun Perjuangan K.H. Irfan Hielmy (Ciamis: Pendar, 2012), hlm. 81.

${ }^{17}$ Ibid., hlm. 26.
} 
hikmah, seperti kisah Lukmanul Hakim dan Sirah Rasulullah SAW. Kemudian, saat ia beranjak remaja ayahandanya mulai mengenalkan ilmu-ilmu syariat, menyuruh menghafal Al-Qur'an dan mendalami ilmu-ilmu bahasa (nahwu, sharaf, balaghah, manthiq dan juga adab al-bahts wa almunazharah). Pendidikan ayahandanya yang seperti itu bersesuaian dengan latar belakang keluarganya yang kental akan pola asuh religius khas pesantren.

Selain dari ayahandanya, K.H. Irfan Hielmy juga pernah belajar kepada beberapa guru meskipun tidak berlangsung lama, seperti belajar ilmu alat dan ushul fiqh kepada Ajengan Zaenal Mustopa, belajar di Pesantren Cintawana di bawah asuhan K.H. Ishak Farid, belajar Al-Qur'an kepada K.H. Ahmad Siradj/Babah Siradj (sesepuh Pesantren Cijantung Ciamis), belajar ilmu alat Bahasa Arab di Panyawungan (Pasawahan) Bandung dan belajar kepada K.H. Ahmad Sanusi (Ketua PUI Sukabumi dan Pengasuh Pesantren Cantayan Gunung Puyuh Cisaat Sukabumi). ${ }^{18}$ Pendidikan formal mulai didapatkan K.H. Irfan Hielmy saat memasuki usia sekolah. K.H. Irfan

${ }^{18}$ Ibid.
Hielmy masuk ke Volkschool $^{19}$ (Sekolah Rakyat/Sekolah Desa) di Pamalayan Desa Dewasari. Proses pembelajaran di Sekolah Rakyat telah membuka pengetahuan baru bagi K.H. Irfan Hielmy. Ia mulai mengenal kebudayaan dan peradaban lain di luar Islam, Arab dan Sunda. Setelah lulus dari Sekolah Rakyat, ia melanjutkan pendidikannya ke Vervolgschool selama dua tahun di Pamalayan. $^{20}$

Setelah menyelesaikan pendidikan dasar, K.H. Irfan Hielmy melanjutkan sekolah di Sekolah Dagang yang kemudian berubah menjadi Sekolah Menengah Ekonomi Pertama (SMEP) $)^{21}$ di Tasikmalaya. Proses pembelajaran di SMEP ia tempuh hanya selama dua tahun (1951-1952). Ia tidak masuk di kelas satu karena kemampuannya dianggap sudah layak untuk masuk di kelas dua. Selesai menuntaskan

19 Sekolah-sekolah yang disediakan untuk rakyat biasa yang tinggal di desa-desa dengan proses pembelajaran selama tiga tahun dan di Jawa Barat sekolah tersebut terdapat di desadesa lingkungan Bandung, Cirebon dan Ciamis

${ }^{20}$ Ahimsa dan Hastuti, Ziarah 80 Tahun, hlm. 132.

21 Sekolah Dagang atau Sekolah Menengah Ekonomi Pertama merupakan sekolah tingkat lanjutan pertama yang proses pembelajarannya selama tiga tahun. Mata pelajaran yang diberikan adalah pelajaran-pelajaran umum, mengetik, surat-menyurat, tata buku, ilmu dagang dan lain-lain. Marwati Djoenoed Poesponegoro dan Nugroho Notosutanto, Sejarah Nasional Indonesia jilid VI (Jakarta: Balai Pustaka, 1984), hlm. 187. 
pendidikan SMEP, K.H. Irfan Hielmy berniat untuk menimba ilmu di Pesantren Darussalam Gontor Ponorogo. Menurut putranya yang keempat, Fadlil Yani Ainusyamsi bahwa K.H. Irfan Hielmy berangkat ke Jawa Timur untuk menimba ilmu di Pesantren Darussalam Gontor. Akan tetapi, sebelum sampai Ponorogo ia terserang sakit dan dirawat di Ciberes Solo, sehingga ketika tiba di Ponorogo pendaftaran penerimaan santri baru sudah ditutup dan ia harus mengikuti ujian masuk tahun depan jika ingin menjadi santri di Darussalam Gontor. Akhirnya, ia tinggal di asrama khusus calon santri baru sambil menunggu dibukanya kembali pendaftaran santri baru. Selama kurang lebih satu bulan tinggal di asrama khusus, K.H. Irfan Hielmy sempat mengikuti pengajian dengan para ustadz di antaranya, K.H. Abdullah Maani, K.H. Ahmad Sahal dan K.H. Azzarkasih. K.H. Irfan Hielmy tidak lama tinggal di sana dan memutuskan pulang. Hal itu disebabkan ia terserang penyakit typus, sehingga ia mengurungkan niatnya mondok di Pesantren Darussalam Gontor. $^{22}$

$$
\text { Dalam }
$$

kehidupan bermasyarakat, ia sangat menghargai dan menghormati pendapat yang

${ }^{22}$ Wawancara dengan Fadlil Yani Ainusyamsi pada 30 Januari 2017 pukul 09.27 WIB di Kantor Kepala MTs Darussalam Ciamis. berbeda, sekalipun datang dari santrinya. Ia juga menghormati agama dan budaya-budaya lain, selama itu tidak terkait dengan hal yang berbau prinsip atau akidah. Ia merupakan salah satu kyai yang turut aktif dalam organisasi sosial keagamaan, khususnya di Ciamis. Hal ini menunjukan bentuk dari mobilitas sosialnya. Organisasi sosial keagamaan yang diikutinya adalah Persatuan Umat Islam (PUI), Nahdlatul Ulama (NU) dan Muhammadiyah. Selain itu, ia juga pernah aktif di Majelis Ulama Indonesia (MUI), baik Kabupaten Ciamis maupun Provinsi Jawa Barat. Perpindahannya dari satu organisasi ke organisasi lain bukan didasarkan pada sikap like atau dislike terhadap organisasi tertentu, tetapi tampak sebagai proses pembelajarannya yang tiada henti, sehingga pandangan-pandangannya selalu berkembang. ${ }^{23}$ Akan tetapi, ketika memasuki pertengahan 1980-an, sikap keagamaannya lebih netral tanpa memihak satu organisasi pun, meskipun secara pemikiran terkadang memiliki kecenderungan atau kemiripan dengan suatu organisasi.

Dalam bidang politik, K.H. Irfan Hielmy tidak hanya bertindak

23 Wawancara dengan Maman Abdul Malik pada 22 Februari 2017 pukul 16.43 WIB di kediamannya. 
secara teoretis melalui pemikiranpemikirannya, tetapi terjun langsung dalam kegiatan politik praktis. Keikutsertaannya dalam politik praktis berlandaskan pada prinsip kaidah ushul fiqh yang berbunyi: $m \hat{a}$ lâ yudraku kulluhu lâ yutraku kulluhu (sesuatu yang tidak dapat diraih seluruhnya/seutuhnya, tidak ditinggalkan seluruhnya/seutuhnya). Ia mulai ikut aktif dalam politik praktis sejak tahun 1964, yaitu sebagai anggota partai NU. Keikutsertaannya dalam partai NU mengantarkannya menjadi anggota DPRD GR (Dewan Perwakilan Rakyat Daerah Gotong Royong) Ciamis periode 1967-1971. Saat itu, ia mewakili tokoh kyai dan ulama daerah Ciamis. Setelah itu ia masuk menjadi bagian dari organisasi politik atau Sekretariat Bersama (Sekber) Golongan Karya (Golkar) dan menjabat sebagai penasihat di tingkat Kabupaten Ciamis sampai tingkat Provinsi Jawa Barat. $^{24}$ Sementara itu, dalam bidang pemikiran, ia dikenal memiliki pemikiran yang takamuliah, yaitu memadukan ilmu dengan amal, agama dengan negara dan kuat terhadap harmoni kehidupan bermasyarakat dan berbangsa. Wawasan keislamannya adalah Islam

${ }^{24}$ Ahimsa dan Hastuti, Ziarah: 80 Tahun, hlm. 174. yang syamil, kamil dan mutakamil. ${ }^{25}$ Hal ini menjadikan pandangannya posisional, yaitu kokoh dalam memegang prinsip dan toleran dalam masalah non-prinsip. Sementara itu, berkenaan dengan pemikirannya tentang hubungan Islam dan politik di Indonesia, telah ia tulis dalam beberapa buku karyanya, seperti Bunga Rampai Menuju Khairu Ummah, Sentuhan Wahyu Penyadar Kalbu dan Wacana Islam: Bahan Telaah Anak Bangsa.

\section{Tinjauan Umum Tentang Khairu Ummah}

Khairu ummah adalah ungkapan ilahiyyah yang sangat luas maknanya dan mendalam hakikatnya serta abadi tujuannya. Jika khairu ummah telah merupakan kenyataan dalam sikap hidup, akan semarak sebuah bangsa, khususnya umat Islam sebagai umat yang dibanggakan, disegani, dihormati dan diperhitungkan oleh segala lapisan masyarakat sepanjang zaman. $^{26}$ Untuk mampu mengimplementasikan khairu ummah dalam sikap hidup, dibutuhkan keuletan dan ketekunan disertai ilmu dan pengetahuan.

25 Badriyyah, K.H. Irfan Hielmy: Pemimpin Moderat, hlm. 3.

26 Hielmy, Bunga Rampai Menuju Khairu Ummah I, hlm. 19. 
Frasa khairu ummah terdapat dalam al-Quran surat Ali Imran ayat 110 yang berbunyi:

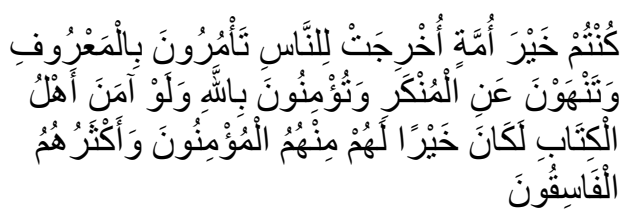

Artinya:

"kamu adalah umat yang terbaik yang dilahirkan untuk manusia, menyuruh kepada yang ma'ruf, dan mencegah dari yang munkar, dan beriman kepada Allah. Sekiranya ahli kitab beriman, tentulah itu lebih baik bagi mereka. Di antara mereka ada yang beriman, namun kebanyakan mereka adalah orangorang yang fasik."

Secara etimologis, kata khair memiliki arti sebaik-baik atau paling baik atau yang terbaik dan kata ummah memiliki arti jamaah atau kelompok. Jika dipahami sekilas, khairu ummah berarti sebaik-baiknya kelompok atau kelompok terbaik atau jamaah paling baik. Bertitik tolak dari ayat di atas, khairu ummah merupakan bentuk ideal masyarakat Islam yang identitasnya adalah integritas keimanan, orientasi dan komitmen kontribusi positif kepada kemanusiaan secara universal dan loyalitas pada kebenaran dengan mekanisme amr bi al-ma'ruf nahy 'an al-munkar. ${ }^{27}$

27 Ali Nurdin, Quranic Society: Menulusuri Konsep Masyarakat Ideal dalam Al-Quran (Jakarta: Penerbit Erlangga, 2006), hlm. 115.
Menurut surat Ali Imran ayat 110, khairu ummah mempunyai tiga dimensi amaliah utama, yaitu amr bi al-ma'ruf, nahy 'an al-munkar dan tu'minûna billah. Sekelompok umat yang ingin mencapai predikat khairu ummah harus mempunyai ketiga dimensi tersebut. Ketiga dimensi amaliah tersebut tidak hanya cukup dengan pengakuan saja, bahkan tidak cukup dengan hanya mendirikan shalat, berpuasa, berzakat, menunaikan haji, menjauhi yang haram dan melaksanakan yang halal. Akan tetapi, harus mampu dan sanggup menyuruh pada kebaikan, melarang pada kemunkaran (amr bi al-ma'ruf nahy 'an al-munkar) dan ber-i'tishâm (berpegang teguh) pada dînullah serta menjauhi ikhtilâf yang menyebabkan iftirâq. ${ }^{28}$ Secara sekilas dapat dikatakan bahwa khairu ummah adalah sekelompok umat yang tidak hanya memiliki kesalehan individu saja, melainkan juga kesalehan sosial.

Istilah khairu ummah dalam bahasa Indonesia sering disebut dengan masyarakat madani. Pendapat ini sebagaimana diuraikan oleh M. Dawam Rahardjo bahwa masyarakat madani itu mengandung tiga hal, yaitu agama sebagai sumber, peradaban sebagai proses

28 Hielmy, Bunga Rampai Menuju Khairu Ummah I, hlm. 20. 
dan masyarakat kota sebagai hasil. ${ }^{29}$ Berdasarkan pendapat ini, khairu ummah merupakan sebuah tatanan ideal masyarakat yang berproses dan untuk diadaptasikan perlu sosialisasi lebih konkret dan rinci. Jika melihat sejarah umat Islam, gambaran paling pertama mengenai masyarakat madani atau khairu ummah dapat dilihat dari pembentukan negara (kota) Yastrib oleh Nabi Muhammad dan umat Islam bersama kaum Yahudi dan Nasrani pada masa klasik yang dalam catatan sejarah dikenal dengan Piagam Madinah. Selain masa klasik, bentuk masyarakat madani atau khairu ummah dapat dilihat pada masa pertengahan, tepatnya masa Kesultanan Turki Utsmani di bawah kekuasaan Sultan Muhammad alFatih. ${ }^{30}$

\section{Menyadari}

bahwa

kemajemukan umat dan bangsa di Indonesia merupakan sebuah realitas empirik yang tidak dapat ditolak dan

${ }^{29}$ M. Dawam Rahardjo, Masyarakat Madani: Agama, kelas Menengah dan Perubahan Sosial (Jakarta: LP3ES, 1999), hlm 145-146.

${ }^{30}$ Bentuk masyarakat madani di masa Sultan Muhammad al-Fatih (Turki Utsmani) dapat dilihat dari penerapan sistem millet yang diberlakukannya setelah keberhasilannya menaklukkan konstantinopel. Ira M Lapidus, Sejarah Sosial Ummat Islam, terj. Ghufron A Mas'adi (Jakarta: RajaGrafindo, 1999), hlm. 496-499 dan Syekh Ramzi al-Munyawi, Muhammad al-Fatih Penakluk Konstantinopel, terj. Muhammad Ihsan (Jakarta: Pustaka alKautsar, 2012), hlm. 171. dinafikan, maka untuk menjaga keharmonisan antar umat dan bangsa diperlukan persatuan, kesatuan dan kebersamaan demi terwujudnya citacita sebuah negara adil makmur yang diridai Allah (baldatun thayyibatun wa rabbun ghafûr) di Indonesia. ${ }^{31}$ Bentuk dan gambaran masyarakat madani atau khairu ummah pada masa klasik dan pertengahan ini yang kiranya telah mendorong K.H. Irfan Hielmy untuk menginterpretasikan masyarakat madani atau khairu ummah dalam konteks keindonesiaan. Oleh sebab itu, gagasan khairu ummah dalam pandangan K.H. Irfan Hielmy, menurut penulis dapat dikategorikan sebagai gagasan, meminjam istilah Mujiburrahman, "Mengindonesiakan Islam". ${ }^{32}$

\section{Realisasi Khairu Ummah Menurut K.H. Irfan Hielmy}

Pandangan khairu ummah yang digagas oleh K.H. Irfan Hielmy

\footnotetext{
${ }^{31}$ Wawancara dengan Fadlil Yani Ainusyamsi.

${ }^{32}$ Setidaknya terdapat tiga ciri yang membentuk gagasan Mengindonesiakan Islam, yaitu (1) Islam yang akomodatif dan transformatif dalam menyikapi budaya lokal dan global; (2) integrasi paham keislaman dan keindonesiaan, keumatan dan kebangsaan; (3) menerima secara positif kemajemukan dan berusaha mengelola kemajemukan itu secara damai dan berkeadilan. Beberapa cendekaiwan yang telah menggagas tema ini adalah Cak Nur dan Gus Dur. Abdul Hamid Yahya dan Yaya, Pemikiran Modern Dalam Islam (Bandung: Pustaka Setia, 2010), hlm. 318.
} 
adalah usahanya merekonstruksi hubungan antara keislaman dan keindonesiaan. Hal ini dilakukan agar umat memiliki pemahaman Islam yang kâffah (utuh) yang mampu dipraktikkan dalam kehidupan sehari-hari. Oleh sebab itu, pandangan khairu ummah-nya dititikberatkan pada strategi-strategi pembangunan sumber daya manusia berkualitas. Dengan demikian, pembangunan sumber daya manusia yang berkualitas yang mampu menyingkirkan pemahaman parsial dan kurang proposional harus bersumber pada al-Quran dan Hadis. ${ }^{33}$ Ia juga menuturkan bahwa predikat khairu ummah yang menjadi cita-cita setiap individu ini harus menjelma dalam kenyataan guna menyemarakkan kebersamaan yang penuh dengan inklusivisme dan tawasut (sikap tengah). Dengan kebersamaan umat akan menjadi kuat dan orang yang kuat akan mampu menciptakan lingkungan, sedangkan orang yang lemah justru harus menyesuaikan diri dengan lingkungan. Jika umat telah kuat, baik fisik maupun pikirnya, maka akan tercipta suatu peradaban yang megah. ${ }^{34}$

${ }^{33}$ Wawancara dengan Koko Komaruddin pada 24 Januari 2016 pukul 20.30 WIB di kediamannya.

${ }^{34}$ Irfan Hielmy, Bunga Rampai Menuju Khairu Ummah I (Ciamis, Pusat Informasi Pondok
K.H. Irfan Hielmy berpendapat bahwa khairu ummah adalah individu-individu yang sanggup mengikis kefanatikan (ta'âshub) dalam berkelompok dan bermadzhab serta sanggup melakukan amr bi alma'ruf nahy 'an al-munkar. Mereka adalah orang-orang yang kuat iman dan mampu mengatasi akal, hati dan nuraninya untuk mengalahkan hawa nafsunya. ${ }^{35}$ Oleh sebab itu, penekanan surat Ali Imran ayat 110 bukan berdasarkan pada khitâb-nya, yaitu Nabi dan para sahabatnya. Akan tetapi, penekanannya ada dalam pelaksanaan amr bi al-ma'ruf nahy 'an al-munkar oleh setiap individu-individu muslim. Dalam hal ini berarti diberlakukan kaidah " al'ibrah bi 'umûm al-lafdzi lâ bi khushûsh al-sabâb". ${ }^{36}$ Dengan demikian, predikat khairu ummah tidak hanya tersematkan pada zaman Nabi dan para sahabatnya, sehingga hal ini harus menjadi sesuatu yang diusahakan, dicita-citakan dan diwujudkan oleh segenap individuindividu Islam.

Guna mewujudkan khairu ummah diperlukan rumusan konkret agar memudahkan mencapai predikat tersebut. Rumusan konkret dari khairu ummah adalah sosok yang

Pesantren Al Fadliliyah Darussalam, 1994), hlm. v-vi.

${ }^{35}$ Ibid., hlm. 21.

36 Hikmah itu diambil dari keumuman lafadz bukan dari kekhususan sebab. 
disebut oleh al-Ghazali dengan insân kamîl. K.H. Irfan Hielmy memandang insan kamil itu adalah Nabi Muhammad, yakni insan yang memperoleh wahyu dari Allah dilengkapi dengan sifat shiddîq (benar), amânah (dapat dipercaya), tablîgh (menyampaikan) dan fathânah (tajam pikiran, cerdas, cerdik). ${ }^{37}$ Meskipun demikian, bukan berarti predikat insân kamîl yang berujung pada terbentuknya khairu ummah tidak dapat dicapai oleh manusia selain Nabi. Hal ini karena insan kamil merupakan kualitas kemanusiaan tertinggi, maka seyogyanya setiap manusia berusaha semaksimal mungkin untuk mencapai derajat kemanusiaan tertinggi itu. K.H. Irfan Hielmy telah memberikan indikator-indikator dari insân kamîl tersebut, yaitu manusia yang kuat akidahnya; (2) manusia yang berakhlak mulia; (3) manusia yang memiliki wawasan luas; (4) manusia yang mempunyai visi tajam; (5) manusia yang bersikap bijaksana (6) manusia yang penuh kelembutan. ${ }^{38}$

Bagi terwujudnya indikator tersebut dalam diri setiap umat dan bangsa, K.H. Irfan Hielmy mengerucutkan indikator tersebut

37 Hielmy, Bunga Rampai Menuju Khairu Ummah III, hlm. 19.

38 Buku Pegangan Daura Tassalam (Taaruf Santri Darussalam) 2016, hlm. dalam trilogi strategi budaya yang digagasnya, yaitu rumusan konsep muslim moderat, mukmin demokrat dan muhsin diplomat. ${ }^{39}$ Ketiga konsep ini merupakan ijtihad K.H. Irfan Hielmy sebagai usahanya dalam rangka mewujudkan khairu ummah melalui pembentukan karakter yang berkualitas. Selain itu, K.H. Irfan Hielmy juga menyatakan bahwa untuk dapat merealisasikan khairu ummah seseorang harus memiliki jiwa-jiwa muwahhid ${ }^{40}$, mujâhid $^{41}, \quad$ mujtahid $^{42}$ dan mujaddid. $^{43}$

Jika di-nisbah-kan dengan ushûluddîn atau dasar-dasar agama, yaitu akidah, syariah dan akhlak, maka akidah adalah yang melahirkan sosok mukmin, syariah melahirkan sosok muslim dan akhlak melahirkan sosok muhsin. ${ }^{44}$ Kemudian, tipologi mukmin, muslim dan muhsin itu masing-masing digandengkan

\footnotetext{
${ }^{39}$ Wawancara dengan Koko Komaruddin.

40 Seseorang yang jiwa dan raganya penuh dengan tauhid, siap dan sanggup melaksanakan titah Allah dengan penuh ketaatan hati, kata dan perbuatan.

${ }^{41}$ Seseorang yang bersedia untuk berkorban demi agamanya, negaranya, masyarakatnya dan keluarganya semata-mata hanya mengharap ridha Allah.

${ }^{42}$ Sosok sarjana, ilmuwan atau apapun namanya yang memiliki kesanggupan menyingkap berbagai ilmu-ilmu Allah, baik yang terkandung dalam ayat-ayat qauliyah maupun kauniyah.

43 Sosok yang mampu memperbarui dan memperbaiki kondisi umat dalam berbagai bidang kehidupan.

${ }^{44}$ Wawancara dengan Koko komaruddin.
} 
dengan nilai-nilai demokrasi, moderasi dan diplomasi. Karena bagi K.H. Irfan Hielmy, tidak ada kontradiksi antara Islam dan moderasi, iman dan demokrasi, serta ihsan dan diplomasi. ${ }^{45}$

Untuk lebih memudahkan dalam pemahaman dan pengaplikasian, K.H. Irfan Hielmy telah memberikan definisi masing-masing dari muslim moderat, mukmin demokrat dan muhsin diplomat. Muslim moderat adalah sosok muslim yang dapat bersikap luwes, tenggang rasa, bersolidaritas etis dan sosial, hormat pada sesama, jauh dari sikap angkuh, congkak dan ingin menang sendiri. Mukmin demokrat adalah sosok manusia beriman yang berakar ke bawah dan berpucuk ke atas. Pada saat di panggung kekuasaan dia tidak melupakan rakyat yang telah membesarkannya dan pada saat dia turun dari panggung kekuasaan dan harus kembali dengan rakyat, dia tidak putus semangat dan putus harapan. Muhsin diplomat adalah sosok manusia yang mencintai kejujuran, keadilan, keberanian, kebajikan, keindahan, sopan santun dan berakhlak mulia. Ia akan mengedepankan sifat-sifat yang baik dan terpuji dalam menghadapi

45 Muhammad Ali, "Kemajemukan Islam Indonesia dan Pendidikan Karakter Bangsa" dalam Ahimsa dan Hastuti, Ziarah: 80 Tahun, hlm. 217. berbagai persoalan hidup dan kehidupan. ${ }^{46}$ Kesatuan dari muslim moderat, mukmin demokrat dan muhsin diplomat ini yang disebut insân kamîl atau muttaqîn. Oleh karena itu, ketiga konsep ini saling terkait dan tidak dapat terpisahkan.

Langkah yang dapat ditempuh untuk mencapai predikat insân kamîl menurut K.H. Irfan Hielmy adalah dengan mengembangkan potensi yang ada pada diri manusia, baik potensi jasmani maupun potensi rohani. Dalam artian, pembangunan sumber daya manusia yang berkualitas harus mempertimbangkan aspek keseimbangan antara kualitas jasmani yang ditandai dengan kesehatan badan dan kualitas rohani yang mencakup daya fikir, daya dzikir, akhlak dan moral. ${ }^{47}$ Dengan demikian, setelah dapat memahami dan mengerti karakteristik insân kamîl terciptanya sekelompok umat yang mampu menjadi agen transformasi sosial Islam melalui cara mengaktualisasikan nilai-nilai keimanan, keislaman dan keihsanan pada realitas objektif kehidupan masyarakat, sehingga terbentuk masyarakat ideal (khairu ummah) atau masyarakat madani yang penuh

46 Buku Pegangan Daura Tassalam (Taaruf Santri Darussalam) 2016, hlm. 20.

${ }^{47}$ Irfan Hielmy, Bunga Rampai Menuju Khairu Ummah III (Ciamis: Pusat Informasi Pondok Pesantren Darussalam, 1999), hlm. 18. 
dengan keadilan, persamaan, persatuan dan kesatuan serta toleransi, bukanlah hal yang mustahil dan sulit dicapai. ${ }^{48}$

\section{E. Penutup}

Pemikiran K.H. Irfan Hielmy tentang khairu ummah di sini adalah berkenaan mengenai usaha-usaha untuk mewujudkan khairu ummah atau tatanan masyarakat ideal di Indonesia. Menurutnya, khairu ummah dapat terwujud ketika orangorang Islam mampu menjadi sosok muslim yang moderat, mukmin yang demokrat dan muhsin yang diplomat. Ketika suatu umat mampu menjelmakan ketiga konsep tersebut dalam diri masing-masing akan terwujud khairu ummah yang berlandaskan ukhuwwah islâmiyyah dan ukhuwwah insâniyyah, sehingga kerukunan intra dan antar umat beragama bukan lagi menjadi sekedar angan-angan saja.

Salah satu persoalan di Indonesia adalah begitu marak pertikaian yang mengatasnamakan agama. Pertikaian tersebut seharusnya dapat diredam dan tidak muncul ke permukaan bila umat dan bangsa bersatu serta mengingat dan memahami sejarah perjuangan kemerdekaan. Sehubungan dengan itu, layak dikemukakan pemikiran

48 Hielmy, Bunga Rampai Menuju Khairu Ummah III, hlm. 44.
K.H. Irfan Hielmy, setidaknya untuk kalangan orang beragama Islam, sehingga lebih mampu hidup berdampingan dan bersama-sama sebagai suatu bangsa. Selain itu, dengan tercerminnya sikap toleransi, maka konsekuensi logis jika umat beragama yang lain pun menghormati dan menghargai Islam.

\section{Daftar Pustaka}

Abdurahman, Dudung. Metodologi Penelitian Sejarah Islam. Yogyakarta: Ombak, 2011.

Ahimsa, Dedi dan Yussi Dewi Hastuti. Ziarah: 80 Tahun Menapaki Perjuangan K.H. Irfan Hielmy. Ciamis: Pendar, 2012.

Badriyyah, Eulis Sri Rosyidatul. K.H. Irfan Hielmy Pemimpin Moderat Panutan Umat. Bandung: Mega Rancage, 2016.

Gazalba, Sidi. Pengantar Sejarah Sebagai Ilmu. Jakarta: Bhatara, 1996

Hielmy, Irfan. Bunga Rampai Menuju Khairu Ummah I. Ciamis: Pusat Informasi Pondok Pesantren Darussalam, 1994. . Bunga Rampai Menuju Khairu Ummah III. Ciamis: Pusat Informasi Pondok Pesantren Darussalam, 1999. 
Wacana Islam: Bahan

Telaah Anak Bangsa. Ciamis:

Pusat Informasi Pondok

Pesantren Darussalam, 2000.

Kuntowijoyo. Identitas Politik Umat Islam. Bandung: Mizan, 1997.

Lapidus, Ira M. Sejarah Sosial Ummat Islam. Terj. Ghufron A Mas'adi. Jakarta: RajaGrafindo, 1999.

Latif, Yudi. Inteligensia Muslim dan Kuasa: Genealogi Inteligensia Muslim Indonesia Abad ke-20. Jakarta: Democracy Project, 2012.

M. Tahir. "Hubungan Agama dan Negara di Indonesia dalam Pandangan Nurcholish Madjid". Jurnal Komunikasi dan Sosial Keagamaan, Vol. XV No. 1, (Juni 2012).

Madjid, Nurcholish. Islam Doktrin dan Peradaban: Sebuah Telaah Kritis tentang Masalah Keimanan, Kemanusiaan dan Kemodernan. Jakarta: Yayasan Wakaf Paramadina, 1992.

al-Munyawi, Syekh Ramzi. Muhammad al-Fatih Penakluk Konstantinopel.
Muhammad Ihsan. Jakarta: Pustaka al-Kautsar, 2012.

Nasution, Harun. Islam Ditinjau dari Berbagai Aspeknya. Jilid I. Jakarta: UI Press, 2013.

Nurdin, Ali. Quranic Society: Menulusuri Konsep Masyarakat Ideal dalam Al-Quran. Jakarta: Penerbit Erlangga, 2006.

Poesponegoro, Marwati Djoenoed dan Nugroho Notosutanto. Sejarah Nasional Indonesia Jilid VI. Jakarta: Balai Pustaka, 1984.

Rahardjo, M. Dawam. Masyarakat Madani: Agama, kelas Menengah dan Perubahan Sosial. Jakarta: LP3ES, 1999.

Syamsuddin, Din. "NKRI: Negara Perjanjian dan Kesaksian", dalam Akhmad Sahal dan Munawir Aziz (ed.). Islam Nusantara: Dari Ushûl Fiqh Hingga Faham Kebangsaan. Bandung: Mizan, 2015.

Yahya, Abdul Hamid dan Yaya. Pemikiran Modern Dalam Islam. Bandung: Pustaka Setia, 2010. 